\title{
Influence of non-cellulose structural carbohydrate composition on plant material decomposition in soil
}

\author{
Sophie Gunnarsson • Håkan Marstorp • \\ A Sigrun Dahlin • Ernst Witter
}

Received: 26 February 2008 /Revised: 15 May 2008 / Accepted: 16 May 2008 / Published online: 17 June 2008

(C) The Author(s) 2008

\begin{abstract}
The $\mathrm{C}$ mineralisation pattern during the early stage of decomposition of plant materials is largely determined by their content of different carbohydrates. This study investigated whether detailed plant analysis could provide a better prediction of $\mathrm{C}$ mineralisation during decomposition than proximate analysis [neutral detergent solution (NDF)/acid detergent solution (ADF)]. The detailed analysis included sugars, fructans, starch, pectin, cellulose, lignin and organic N. To determine whether differences in decomposition rate were related to differences in hemicellulose composition, the analysis particularly emphasised the concentrations of arabinose and xylose in hemicelluloses. Carbon dioxide evolution was monitored hourly in soil amended with ten different plant materials. Principal component and regression analysis showed that $\mathrm{C}$ mineralisation during day 1 was closely related to free sugars, fructans and soluble organic $\mathrm{N}$ components $\left(R^{2}=\right.$ $0.83)$. The sum of non-cellulose structural carbohydrates (intermediate NDF/ADF fraction) was not related to $\mathrm{C}$ mineralisation between days 1 and 9 . In contrast, a model including starch and protein in addition to the non-cellulose structural carbohydrates, with the hemicelluloses replaced by arabinose and xylose, showed a strong relationship with evolved $\mathrm{CO}_{2}\left(R^{2}=0.87\right)$. Carbon mineralisation between days 9 and 34 was better explained by xylan, cellulose and lignin $\left(R^{2}=0.72\right)$ than by lignocellulose in the $\mathrm{ADF}$ fraction. Our results indicated that proximate analyses were not sufficient to explain differences in decomposition. To predict $\mathrm{C}$ mineralisation from the range of plant materials
\end{abstract}

S. Gunnarsson · H. Marstorp • A. S. Dahlin $(\bowtie) \cdot$ E. Witter Department of Soil and Environment, Swedish University of Agricultural Sciences, Box 7014, 75007 Uppsala, Sweden e-mail: Sigrun.Dahlin@mv.slu.se studied, we propose a minimum set of analyses comprising total N, free sugars, starch, arabinose, xylan, cellulose and lignin.

Keywords C mineralisation · Plant material $\cdot \mathrm{NDF} / \mathrm{ADF}$. Arabinose $\cdot$ Xylose

\section{Introduction}

Differences in the chemical composition of plant materials affect the temporal pattern of their decomposition in soil. Because the decomposition process is closely linked to plant nutrient cycles, particularly that of nitrogen, the decomposition pattern of plant materials added to soil has a pronounced effect on temporal changes in soil $\mathrm{N}$ availability. Being able to predict the timing (and amplitude) of these changes on the basis of the chemical composition of plant materials is important for efficient management of soil $\mathrm{N}$ after addition of plant materials such as green manures.

Many studies have shown that during the initial few days of plant material decomposition in soil, soluble carbohydrates such as free sugars and fructans are decomposed together with the most readily degradable N-rich components (Kühbauch and Kleeberger 1975; Martin and Haider 1986; Marstorp 1996, 1997; Trinsoutrot et al. 2000; Gunnarsson and Marstorp 2002). Studies in both soil and the rumen environment show that after these initial few days, proteins, and to a large extent also non-cellulose structural carbohydrates such as pectic substances, hemicellulose constituents and cellulose, are sequentially degraded (Martin and Haider 1986; Nordkvist et al. 1987; Henriksen and Breland 1999; Gunnarsson and Marstorp 2002). 
In decomposition studies, proximate analyses are commonly used to determine plant material composition (Quemada and Cabrera 1995; Henriksen and Breland 1999; Gunnarsson and Marstorp 2002; Seguin et al. 2002; Henriksen et al. 2007). A widely used proximate analysis is the neutral detergent solution (NDF)/acid detergent solution (ADF) method (Goering and van Soest 1970) with which plant materials are extracted under reflux successively with a NDF and an ADF. The three fractions obtained by this analysis consist mainly of hot water-soluble components and proteins, non-cellulose structural carbohydrates including hemicelluloses and pectin and non-extractable lignocellulose residue. The method does not distinguish between pectic substances and hemicelluloses or between different types of hemicelluloses. Consequently, it does not separate plant materials with differing chemical composition in these respects despite their differing rates of degradation as has been shown for stems of Lolium perenne and Trifolium pratense (Gunnarsson and Marstorp 2002). The main constituents of hemicellulose are arabinoxylans, which consist of short side chains of arabinose attached to a backbone chain composed of xylose units (Wilkie 1979; Gruppen et al. 1993; Åman 1993; Vinkx et al. 1995; KögelKnabner 2002). The ratio of arabinose to xylose differs between grasses and legumes, with a higher arabinose content in legumes. Studies in the rumen environment have shown that the arabinose-to-xylose ratio influences the rate of plant material degradation (Albrecht et al. 1987; Vailhé et al. 2000).

The objective of this study was to determine whether a more detailed plant analysis than that offered by traditional proximate analysis (NDF/ADF) would give a better prediction of the pattern of $\mathrm{C}$ mineralisation during decomposition of a range of plant materials common in temperate agricultural systems. We were especially interested to examine whether determination of the relative proportions of arabinose and xylose in the hemicellulose fraction could help explain differences in $\mathrm{C}$ mineralisation patterns between a range of plant materials including legumes and grasses.

\section{Materials and methods}

\section{Soil and plant materials}

A sandy soil $[12.5 \%$ clay, $25.9 \%$ silt, $51 \%$ sand, $1.63 \%$ total $\mathrm{C}, 0.13 \%$ total $\left.\mathrm{N}, \mathrm{pH}\left(\mathrm{H}_{2} \mathrm{O}\right) 6.1\right]$ from Ultuna in central Sweden $\left(60^{\circ} \mathrm{N}, 17^{\circ} \mathrm{E}\right)$ was used in all experiments. The soil was sieved through a $4-\mathrm{mm}$ mesh and stored at $-20^{\circ} \mathrm{C}$ before use.

The plant materials used in the experiment (Table 1) were grown from seed in pots containing the equivalent of

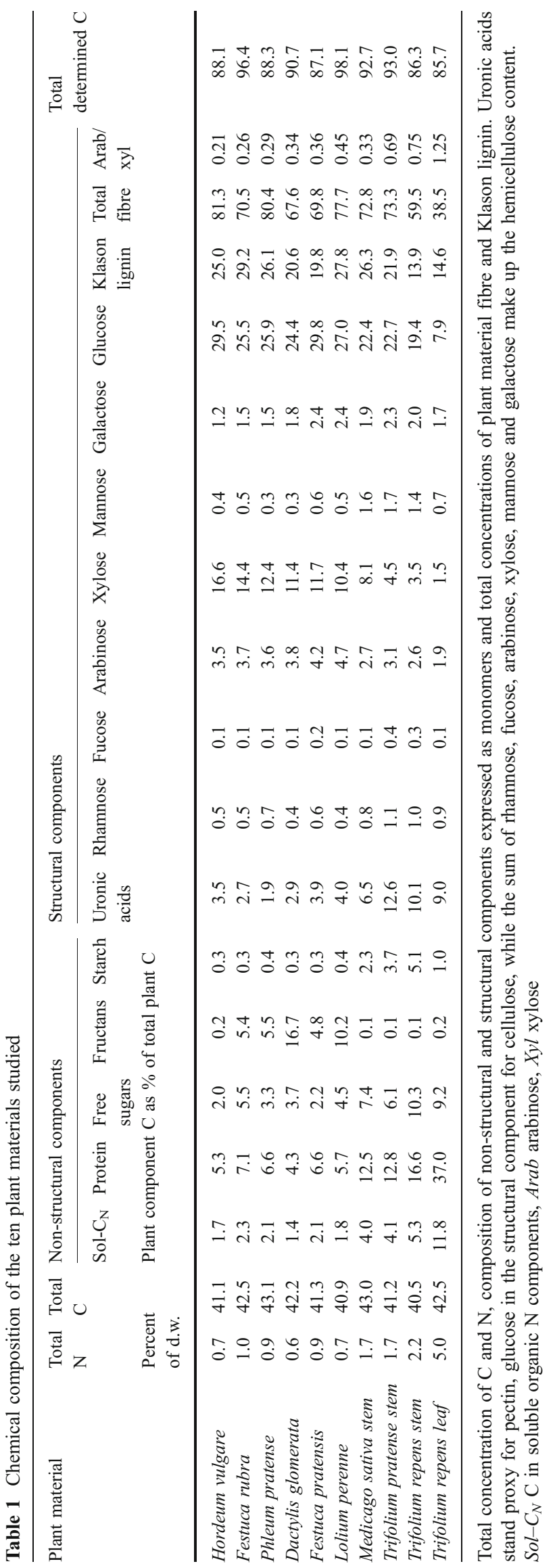


$6 \mathrm{~kg}$ dry weight (dw) soil. Seeds were sown on 1 May, and the pots were placed in an outdoor roofed area and harvested on 23 October. A nutrient solution containing $\mathrm{N} / \mathrm{P} / \mathrm{K}$ in proportions of $1,000: 1,035: 730 \mathrm{mg}$ per pot was added before sowing. Six monocotyledons and three dicotyledons, all common to temperate zone agricultural systems, were chosen to give plant materials a wide range of biochemical characteristics in terms of concentrations of sugars, pectic substances, hemicelluloses and cellulose. The harvested dicotyledon material was separated into leaf and stem. All materials were freeze-dried and stored in the dark until use. Before chemical analysis and experimental use, the plant materials were ground to pass a $1-\mathrm{mm}$ sieve.

Chemical analysis and decomposition studies

The plant materials were analysed chemically according to the overview presented in Fig. 1. Carbon and $\mathrm{N}$ in the plant materials and fibre were determined by dry combustion using an elemental analyser (CNS2000 analyser, Leco Corporation, USA). Water-extractable organic $\mathrm{N}$ compo- nents in the plant materials were obtained by extracting $0.1 \mathrm{~g} \mathrm{dw}$ plant material with $200 \mathrm{ml}$ distilled water for $1 \mathrm{~h}$ at $20^{\circ} \mathrm{C}$. Extracts were analysed for total $\mathrm{N}$ on an automated total $\mathrm{N}$ analyser (TN-05, Mitsubishi, Japan). Concentrations of protein $\mathrm{C}$ and $\mathrm{C}$ in extractable organic $\mathrm{N}$ compounds, presented as protein and soluble N-rich components in Table 1, were calculated by assuming a C-to-N ratio of 3.1. Concentrations of glucose, fructose, sucrose, fructans and starch were determined by enzymatic methods (Larsson and Bengtsson 1983). All analyses were performed in triplicate.

The fibre fraction of the plant materials was defined as amylase-resistant polysaccharides plus lignin. It was isolated as described in Asp et al. (1983) with minor modifications: Sugars, starch and protein were removed from the plant materials through serial enzymatic treatment starting with termamyl (300 L DX, Novo Nordisk) at pH 6.0 and $100^{\circ} \mathrm{C}$ for $25 \mathrm{~min}$ to initiate the degradation of starch. This was followed by addition of pepsin (2000 FIP-U g ${ }^{-1}$, Merck) at $\mathrm{pH} 1.5$ and $40^{\circ} \mathrm{C}$ for $60 \mathrm{~min}$ to degrade the proteins followed by the addition of pancreatine (P-7545, Sigma) at $\mathrm{pH} 6.8$ and $40^{\circ} \mathrm{C}$ for $60 \mathrm{~min}$ to complete the
Fig. 1 Schematic representation of the procedure used for detailed chemical analysis of the plant materials

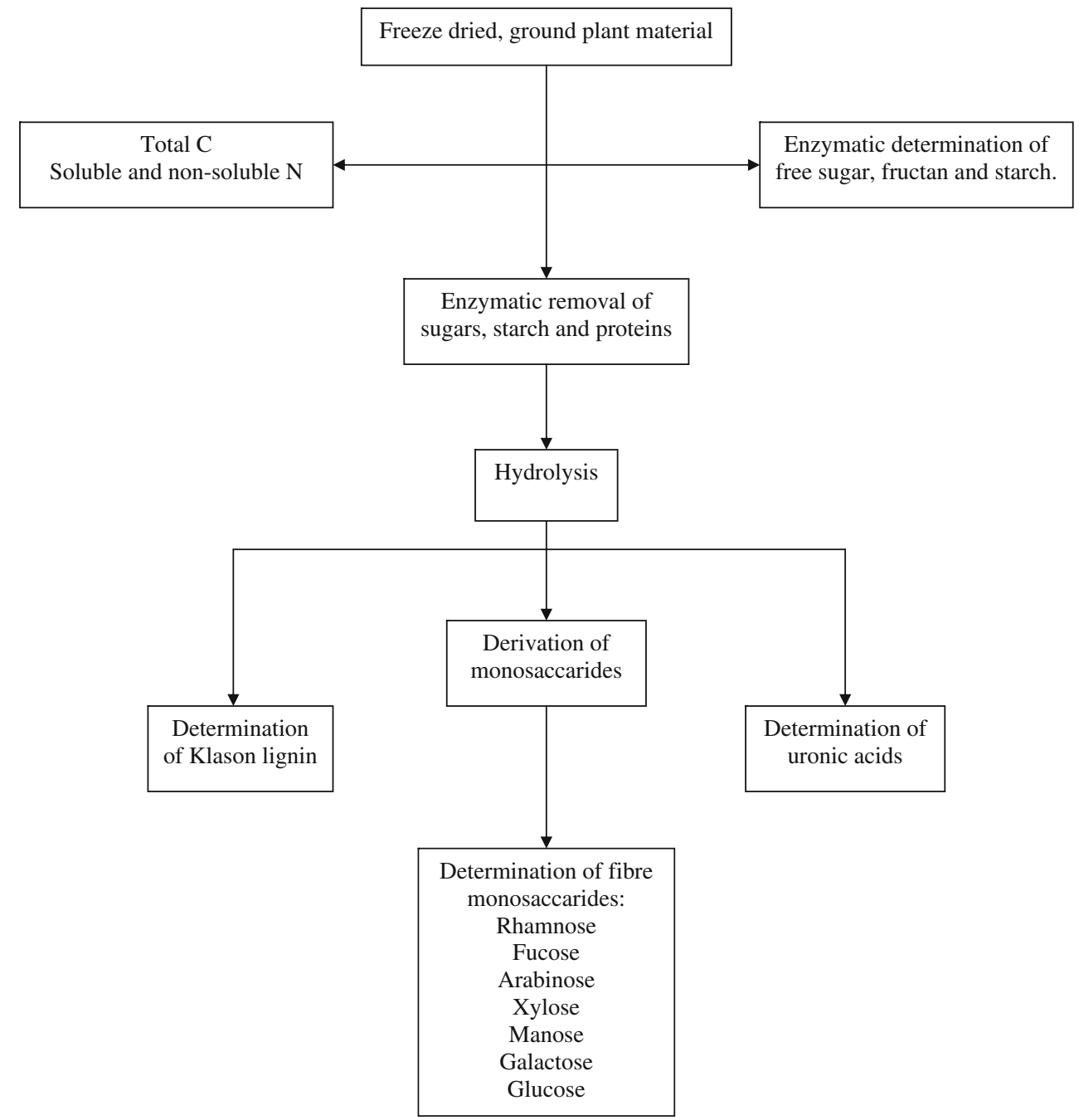


degradation of protein and starch. Thereafter, the $\mathrm{pH}$ was adjusted to 4.5. After precipitation for $60 \mathrm{~min}$ in $95 \%$ ethanol at $60^{\circ} \mathrm{C}$, the insoluble polysaccharides constituting the fibre fraction were recovered by filtration through glass filters with a pore size of $40-90 \mu \mathrm{m}$. The fibre fraction was washed twice with $10 \mathrm{ml} \mathrm{78 \%} \mathrm{ethanol,} \mathrm{twice} \mathrm{with} 10 \mathrm{ml}$ $95 \%$ ethanol and finally twice with $10 \mathrm{ml} \mathrm{99 \%}$ ethanol. The isolated fibre fraction was dried overnight at $105^{\circ} \mathrm{C}$ and determined gravimetrically. After hydrolysis in $12 \mathrm{M}$ $\mathrm{H}_{2} \mathrm{SO}_{4}$, the fibre fraction was analysed for monosaccharides as alditol acetate by gas chromatography (Theander et al. 1995), for pectic substances colorimetrically as uronic acids and for lignin determined gravimetrically as Klason lignin. Cellulose was calculated from glucose monomers of the fiber fraction. Hemicelluloses were calculated as the sum of the non-cellulose structural carbohydrates rhamnose, fucose, arabinose, xylose, mannose and galactose contents in the fibre fraction. Despite the use of a combination of enzymes, small amounts of the plant material may escape degradation, which may lead to exaggerated values for nondetermined $\mathrm{C}$ (Table 1).

To allow comparison with fractions obtained with the $\mathrm{NDF} / \mathrm{ADF}$ method, some of the plant components were grouped together. Thus, the lignocellulose fraction was calculated as the sum of cellulose and Klason lignin in the fibre fraction. A fraction similar to the intermediate fraction obtained with the NDF/ADF method was calculated as hemicelluloses plus pectins. The fraction corresponding to the soluble fraction of the NDF/ADF method was calculated as the difference between the whole plant material and the fibre fraction.

Decomposition of the plant materials to determine their availability as $\mathrm{C}$ and energy sources was measured at $20^{\circ} \mathrm{C}$ in 250-ml plastic jars containing the equivalent of $40 \mathrm{~g}$ dry soil. The soil moisture content was maintained at $45 \%$ of water-holding capacity $\left(0.085 \mathrm{~g} \mathrm{H}_{2} \mathrm{O} \mathrm{g} \mathrm{g}^{-1} \mathrm{dw}\right.$ soil). The equivalent of $0.5 \mathrm{ml}$ nutrient solution containing $\mathrm{N} / \mathrm{P} / \mathrm{K}$ as $\mathrm{KNO}_{3}$ and $\mathrm{K}_{2} \mathrm{PO}_{4}$, in concentrations of $2.8: 0.12: 8.0 \mathrm{mg}$ $\mathrm{ml}^{-1}$, respectively, was added to each jar. Preliminary tests, similar to those described in Nordgren (1992), showed that the addition of this nutrient solution was needed to avoid nutrient-limiting decomposition affecting the $\mathrm{C}$ mineralisation pattern.

The soil was pre-incubated for 10 days before substrate addition. Plant material was then added at a rate of $1,000 \mu \mathrm{g} \mathrm{C} \mathrm{g}^{-1} \mathrm{dw}$ soil on day 0 . The control soil received the nutrient solution only. Each plant material was added to three replicates. To avoid possible effects on microbial degradation by differences in residue-soil contact (e.g. Fruit et al. 1999; Abivens and Recous 2007), the residues were thoroughly mixed into the soil before incubation. The $\mathrm{CO}_{2}$ evolved during decomposition was measured every hour for 34 days using an automatic respirometer (Marstorp
1996) and thereafter by titration (Stotzky 1965) until day 123. The amounts of $\mathrm{CO}_{2}$ evolved were corrected for respiration from the unamended control soil.

\section{Statistical analysis}

Concentrations of individual plant components were expressed as a percentage of total plant material on the basis of their $\mathrm{C}$ contents. The amounts of $\mathrm{CO}_{2}-\mathrm{C}$ evolved during different time intervals (days $0-1,1-3,3-9,9-34$ and 34-123) were used to describe the decomposition pattern. The selection of time intervals was based on data on mineralisation patterns of a number of proteins and of simple and complex carbohydrates common in plant materials (Gunnarsson and Marstorp 2002).

Relationships between plant material composition and the amount of $\mathrm{C}$ mineralised during decomposition were analysed by linear multiple regression using the procedure REG in the SAS statistical analysis package (SAS Institute Inc. 1985). To reduce the number of parameters obtained from the REG analysis, the selected time intervals for $\mathrm{CO}_{2}$ $\mathrm{C}$ evolution were limited to days $0-1,1-9,9-34$ and 34 123.

Principal component analysis (PCA) with the Statistica software package (StatSoft Inc. 2000) was used to classify the plant materials on the basis of their chemical characteristics and pattern of decomposition. All data for PCA analysis were standardised to unit variance.

\section{Results}

Chemical composition of plant materials

The plant materials used in this study covered a wide range of chemical compositions in terms of non-structural and structural components (Table 1). The legumes had a higher free sugar concentration $(6-10 \%)$ than the grasses $(2-6 \%)$, whereas fructan was only found in significant concentrations in the grasses. The legumes had higher concentrations of pectin $(7-13 \%)$ than the grasses $(2-4 \%)$, and also a higher concentration of starch $(1-5 \%)$ than the grasses $(0.3-0.4 \%)$. The concentration of hemicellulose ranged from $7 \%$ to $22 \%$, with the lowest concentration in leaves of Trifolium repens and the highest in Hordeum vulgare straw (Table 1). The ratio of arabinose to xylose was generally lower in the grasses than in the legumes, ranging from 0.21 in $H$. vulgare straw to 1.25 in $T$. repens leaves. This indicates a higher proportion of branched arabinoxylans in the legumes compared with the grasses, which were more dominated by the linear xylans. The concentration of cellulose ranged from $19 \%$ to $30 \%$, except in $T$. repens leaves which only contained $8 \%$ cellulose. The 
concentration of lignin ranged from $14 \%$ to $29 \%$, with the lowest concentrations in stems and leaves from $T$. repens. Total $\mathrm{N}$ concentration was highest in leaves from $T$. repens $(5.0 \%)$ and lowest in straw from D. glomerata $(0.6 \%)$. The $\mathrm{NO}_{3}{ }^{-} \mathrm{N}$ concentration was low in all plant materials (results not shown).

Principal component analysis based on the detailed chemical analysis (Table 1) resulted in a separation of the legumes from the grasses in the first component (Fig. 2a). The first component explained $60 \%$ of the variation, and most variables, except fructan, fucose and galactose, contributed to it. Both soluble components and character- istics of the fibre fraction therefore contributed to this component. The second principal component in which only fucose and galactose had a factor loading greater than 0.7 explained only $18 \%$ of the variation. In this component, $L$. perenne and Festuca pratensis were separated on the basis of differences in their galactose concentration and the legumes on the basis of their fucose concentration. In contrast, analysis of the chemical composition of the plant materials by grouping their components into soluble, noncellulose structural carbohydrates, cellulose and lignin C, i.e. fractions similar to those produced by NDF/ADF analysis, did not result in a clear separation of legumes
Fig. 2 Factor scores of the two principal components obtained from PCA of the plant chemical characteristics (standardised data). a PCA based on detailed chemical analysis, expressed as free sugars, fructans, starch, protein, uronic acids, rhamnose, fucose, arabinose, xylose, mannose, galactose, glucose and Klason lignin. b PCA based on proximate analysis expressed as soluble components, noncellulose structural carbohydrates, cellulose and Klason lignin

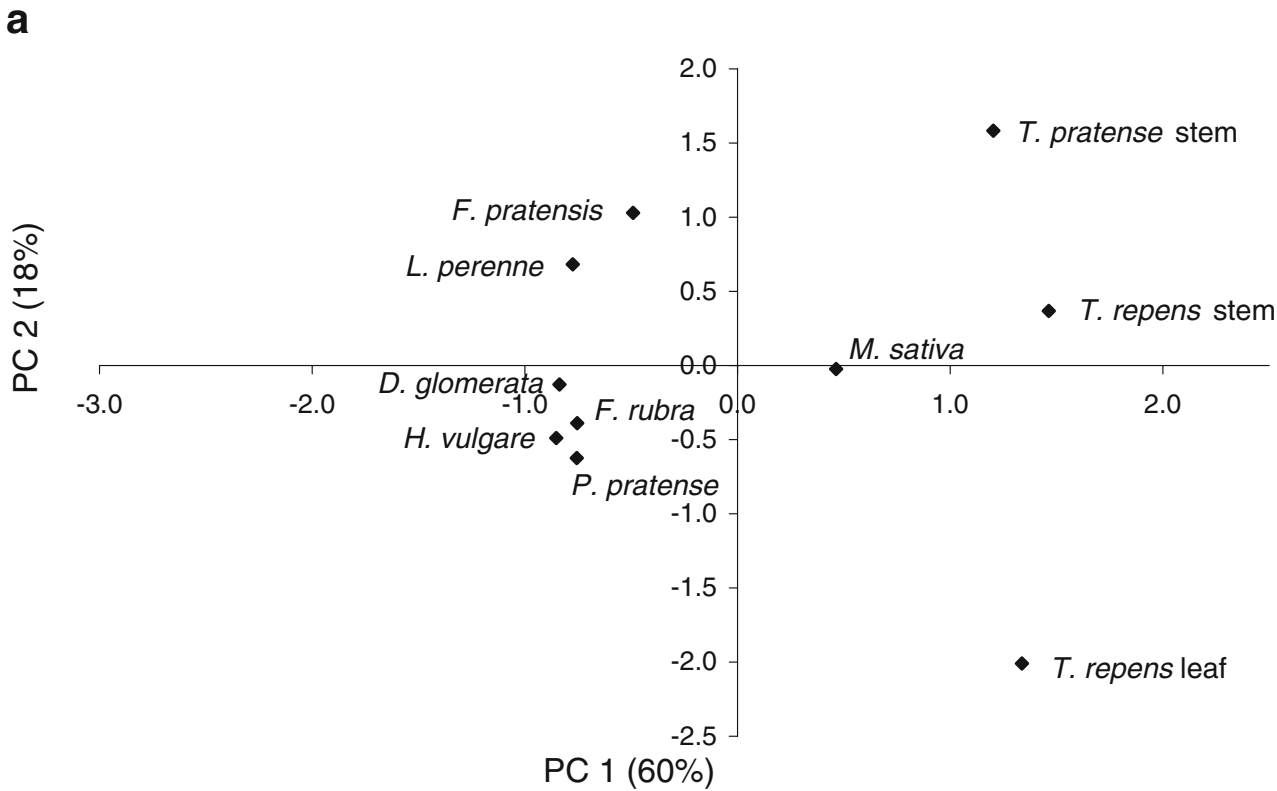

b

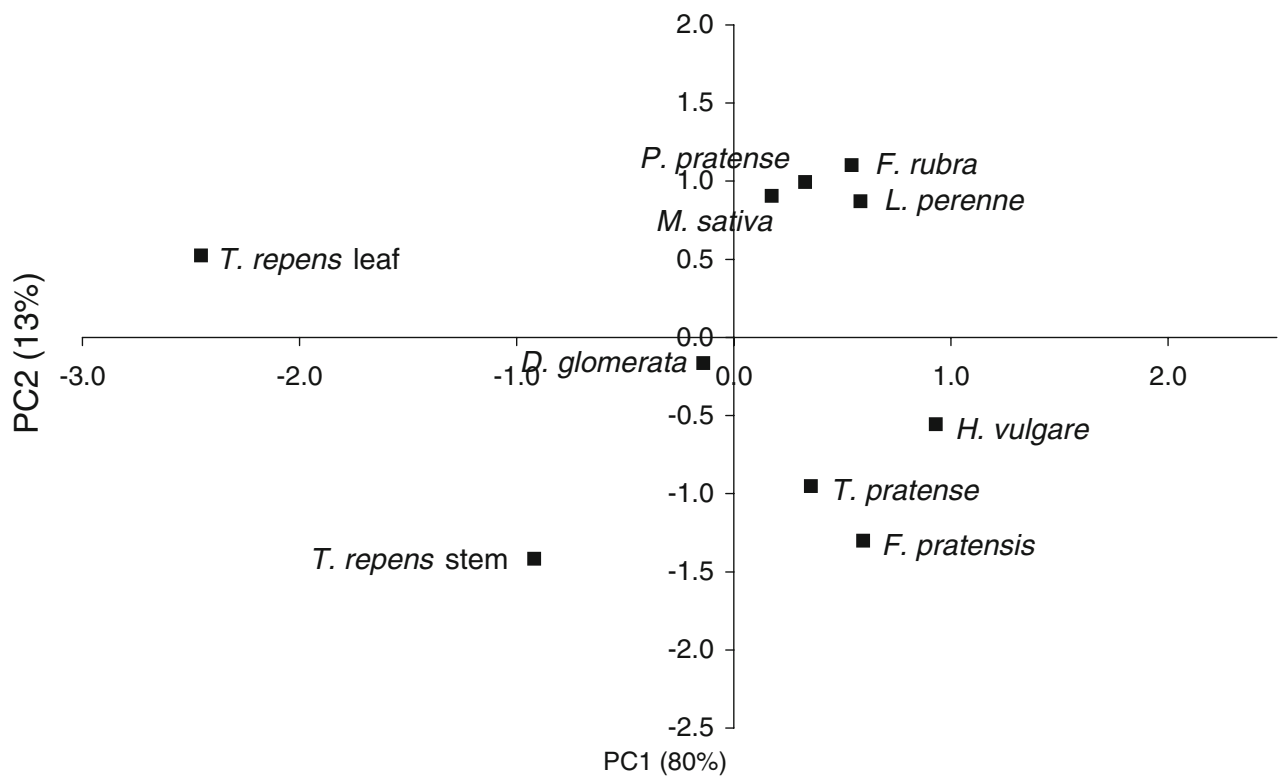


and grasses (Fig. 2b). Only the first component in this analysis had an eigenvalue greater than 1 and explained $80 \%$ of the variation. All variables contributed to this component.

Overall decomposition pattern for legumes and grasses

The grass and straw materials showed a respiration peak during the first day after addition, followed by a second peak around day 5 (Fig. 3). The legume materials also showed a peak during day 1 , and a less distinct secondary peak occurred around day 2 . In contrast to the grasses, there was no respiration maximum on day 5 after addition of legume materials. For two of the legume materials, $T$. repens leaves and stems, the second peak overlapped with the first, giving rise to a tail that lasted for several days. After day 9, similar respiration rates were observed in all materials.
Fig. $3 \mathrm{CO}_{2}-\mathrm{C}$ evolution rate during the first 15 days of plant material decomposition. Error bars give standard error
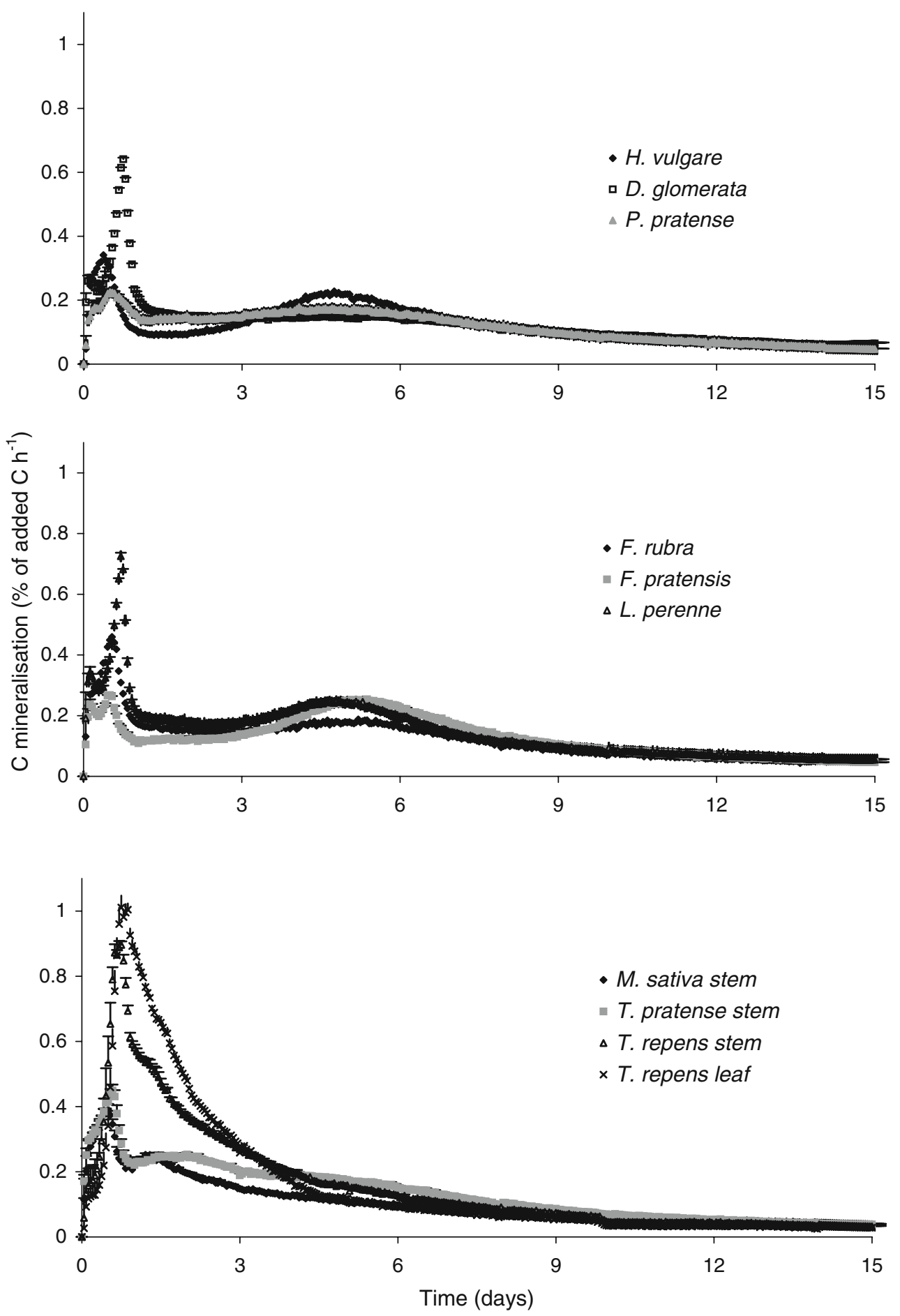
Principal component analysis of the amounts of $\mathrm{C}$ mineralised during the time intervals days $0-1,1-3,3-9$, 9-34 and 34-123 (Table 2) resulted in separation of the legumes from the grasses in the first component (Fig. 4). The first component explained $60 \%$ of the variation and included all time intervals up to day 34. The amount of $\mathrm{C}$ mineralised in the interval days 1-3 had the largest influence on the first component. The second principal component in which only the interval days 34-123 had a factor loading greater than 0.7 explained only $21 \%$ of the variation.

\section{Components contributing to $\mathrm{C}$ mineralisation}

The amount of $\mathrm{C}$ mineralised during day 1 related $\left(\operatorname{adj} . R^{2}=\right.$ 0.77 ) to amounts of $C$ in free sugars and fructan combined in a multiple regression model (Table 3). Adding the $\mathrm{C}$ contained in soluble organic $\mathrm{N}$ compounds to the amounts of fructan and sugar improved the relationship $\left(\operatorname{adj} . R^{2}=\right.$ 0.83 ). The amount of $\mathrm{C}$ mineralised during day 1 was close to, and in some cases exceeded, the amount of $\mathrm{C}$ present in sugars, fructans and soluble organic $\mathrm{N}$ compounds.

Carbon mineralisation between days 1 and 9 was not related (adj. $R^{2}=0.18$; Table 3 ) to the sum of non-cellulose structural carbohydrates, i.e. pectic substances and hemicelluloses. An improved, but still weak, relationship was obtained when a more detailed model containing the amounts of starch, pectin, protein and hemicelluloses was used (adj. $R^{2}=0.47$ ). However, the relationship was greatly improved by exchanging hemicellulose in the model with the variables arabinose and xylose (adj. $R^{2}=0.87$ ). This suggests that the composition of the hemicellulose fraction as described by these two components may be as important an indicator of $\mathrm{C}$ mineralisation in the day 1-9 interval as the total amounts of $\mathrm{C}$ in this fraction. In this regression model, arabinose was the most influential component determining $\mathrm{C}$ mineralisation. The amount of $\mathrm{C}$ mineralised between days 1 and 9 approximately equalled the amounts of $\mathrm{C}$ present in starch, pectin, protein, arabinose and xylose.
The amounts of $\mathrm{C}$ mineralised from the plant materials between days 9 and 34 could be described by a model including xylan, cellulose and lignin (adj. $R^{2}=0.72$; Table 3). Excluding xylan, or excluding xylan and summing lignin and cellulose into a single lignocellulose fraction, weakened this relationship (adj. $R^{2}=0.67$ and 0.57 , respectively). When considering $\mathrm{C}$ mineralisation from day 34 until the end of incubation (day 123) in relation to slowly decomposing components, i.e. xylan and cellulose in combination with lignin, no significant relationship was found (adj. $R^{2}=-0.06$ ).

\section{Discussion}

The most pronounced differences in chemical composition between the grass and legume materials were related to their contents of free sugars, fructans, starch, pectin and the quantity and composition of the hemicelluloses. Legume hemicelluloses were characterised by higher arabinose-toxylose ratios compared with the hemicelluloses found in the grasses, which were dominated by linear xylans. A principal component analysis based on the detailed chemical analysis clearly separated legumes from grasses, whereas one based on NDF/ADF proximate analysis did not. This shows that legumes and grasses can only be differentiated through a more detailed chemical analysis. A corresponding principal component analysis based on $\mathrm{C}$ mineralisation patterns also separated legumes from grasses. This implies that the differences in decomposition pattern of the two groups of materials were due to differences in chemical composition not revealed by the NDF/ADF method and supports our earlier indications (Gunnarsson and Marstorp 2002) that the NDF/ADF method is not sufficient to explain differences in $\mathrm{C}$ mineralisation between legume and grass plant materials.

The amount of $\mathrm{C}$ mineralised during day 1 was related to the levels of sugars, fructans and soluble organic $\mathrm{N}$ compounds, indicating that apart from the levels of easily

Table 2 Amount of $\mathrm{C}$ mineralised (as \% of added C) from plant materials during different time intervals

\begin{tabular}{|c|c|c|c|c|c|c|}
\hline Plant material & Days $0-1$ & Day $1-3$ & Day 3-9 & Days 9-34 & Days $34-123$ & Days $0-123$ \\
\hline H. vulgare & $5.1(0.05)$ & $4.9(0.07)$ & $23.1(0.14)$ & $24.0(0.36)$ & $19.8(2.67)$ & $76.9(2.52)$ \\
\hline D. glomerata & $8.1(0.22)$ & $7.4(0.20)$ & $19.4(0.26)$ & $24.8(0.18)$ & $22.8(3.70)$ & $82.5(2.51)$ \\
\hline P. pratense & $4.3(0.19)$ & $6.9(0.07)$ & $21.0(0.11)$ & $21.2(0.46)$ & $10.9(1.83)$ & $64.3(2.07)$ \\
\hline F. rubra & $7.1(0.08)$ & $7.3(0.17)$ & $20.7(0.19)$ & $19.8(0.23)$ & $13.9(4.07)$ & $68.8(3.88)$ \\
\hline F. pratensis & $4.4(0.24)$ & $5.9(0.09)$ & $26.2(0.39)$ & $21.4(0.98)$ & $22.5(4.72)$ & $80.4(3.78)$ \\
\hline L. perenne & $9.0(0.15)$ & $8.6(0.15)$ & $25.4(0.24)$ & $23.6(1.51)$ & $17.4(4.68)$ & $84.0(2.34)$ \\
\hline M. sativa & $6.6(0.39)$ & $9.5(0.18)$ & $14.3(0.16)$ & $16.8(0.32)$ & $7.2(1.41)$ & $54.4(0.55)$ \\
\hline T. pratense & $7.5(0.21)$ & $11.2(0.36)$ & $21.1(0.42)$ & $17.7(0.20)$ & $26.4(6.66)$ & $83.9(6.39)$ \\
\hline T. repens (stem) & $12.0(0.61)$ & $16.8(0.14)$ & $21.2(0.31)$ & $15.8(1.43)$ & $4.8(1.89)$ & $70.6(1.14)$ \\
\hline T. repens (leaf) & $12.2(0.73)$ & $24.2(0.35)$ & $16.1(0.40)$ & $11.5(1.15)$ & $20.5(0.72)$ & $84.5(2.69)$ \\
\hline
\end{tabular}

Values within parenthesis are standard errors of the mean $(n=3)$ 
Fig. 4 Factor scores of the two principal components obtained from PCA of amounts of C mineralised during the periods days $0-1 ; 1-3 ; 3-9 ; 9-34$ and 34-123 (standardised data)

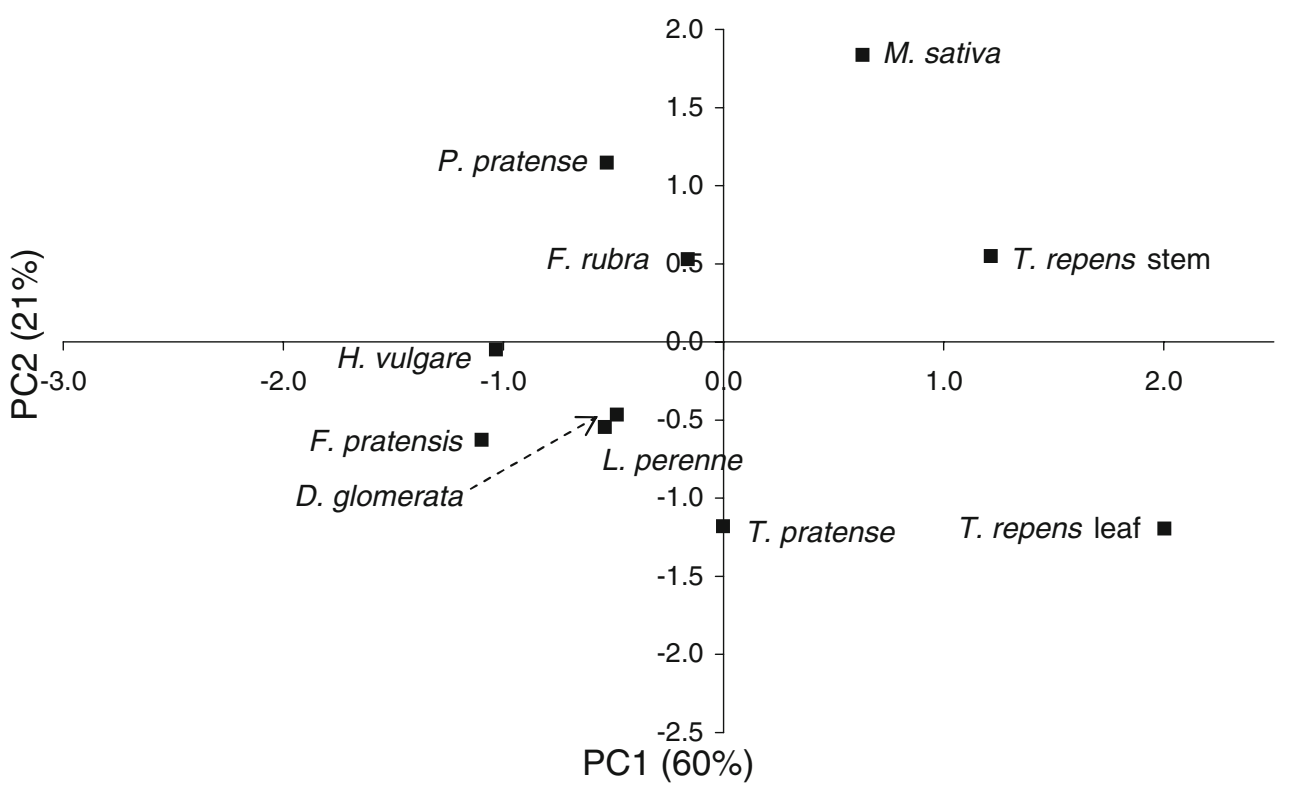

degradable storage carbohydrates, the organic $\mathrm{N}$ compounds are also decomposed during the first day. The amounts of $\mathrm{C}$ in these carbohydrates and $\mathrm{N}$ compounds were, however, insufficient to explain all of the $\mathrm{C}$ mineralised, as the amount of $\mathrm{C}$ in these compounds was close to the amounts of $\mathrm{C}$ mineralised. This indicates that although the $\mathrm{C}$ mineralisation was mainly determined by the amounts of these compounds (adj. $R^{2}=0.83$ ), other components were also being decomposed. Earlier, we found that starch and proteins as well as some structural carbohydrates can start to decompose very early although at a low rate (Gunnarsson and Marstorp 2002) and may therefore have contributed to $\mathrm{C}$ mineralisation during the first day of decomposition.

Carbon mineralisation between days 1 and 9 was very weakly related to the sum of non-cellulose structural carbohydrates. The relationship was improved by taking the protein content into account, but the largest improvement was obtained by including the amounts of hemicel- lulose, with especially the arabinose content, being a determinant for $\mathrm{C}$ mineralisation. Studies in the rumen environment have shown that arabinose is degraded more rapidly than xylose (Åman 1985; Nordkvist and Åman 1986; Albrecht et al. 1987; Jung et al. 1998). However, the rate of degradation of arabinoxylans in grasses has been found to decrease with increasing degree of branching, as indicated by an increase in the arabinose-to-xylose ratio (Albrecht et al. 1987; Bertrand et al. 2006). On the other hand, Vailhé et al. (2000) found a positive correlation between the arabinose-to-xylose ratio and degradation rate. Clearly, the type of relationship obtained between a particular plant component and the degradation rate depends on the types of plant materials included in the comparison. Our study included legumes and grasses, with the latter having low arabinose-toxylose ratios. As mentioned earlier, inclusion in the statistical analysis of detailed chemical data, including data on arabinose and xylose, separated grasses from legumes but also resulted in much improved relationships between degradation and

Table 3 Regression models describing the relationship between $\mathrm{C}$ mineralisation $\left(\mathrm{mg} \mathrm{C} \mathrm{g}^{-1}\right.$ added $\mathrm{C}$ ) during different time intervals and plant chemical components based on either proximate or detailed analysis

\begin{tabular}{|c|c|c|c|c|c|c|c|}
\hline Time interval (days) & Intercept & Regression coefficients & & & & & Adj. $R^{2}$ \\
\hline $0-1$ & $1.52 *$ & 0.98 Sug*** & 0.167 Fruct** & & & & $0.77 * * *$ \\
\hline $0-1$ & 1.15 & 0.46 Sug* & 0.25 Fruct*** & $1.68 \mathrm{Sol}-\mathrm{C}_{\mathrm{N}} * *$ & & & $0.83 * * *$ \\
\hline $1-9$ & $48.84 * * *$ & -0.81 Non-cell* & & & & & $0.18^{*}$ \\
\hline $1-9$ & $29.32 *$ & -0.03 Starch & $0.25 \mathrm{Ua}$ & $-0.16 \mathrm{Hemi}$ & 0.26 Prot & & $0.47 * * *$ \\
\hline $1-9$ & $-33.00 * * *$ & $3.88 \mathrm{Starch}^{* * *}$ & $-0.40 \mathrm{Ua}$ & $11.15 \mathrm{Arab}^{* * *}$ & $0.82 \mathrm{Xyl}^{* *}$ & 1.37 Prot*** & $0.87 * * *$ \\
\hline $9-34$ & $5.06^{*}$ & 0.32 LigCell $^{* * *}$ & & & & & $0.57 * * *$ \\
\hline $9-34$ & $6.30 * *$ & 0.57 Cell $* * *$ & $-0.01 \mathrm{Lig}$ & & & & $0.67 * * *$ \\
\hline $9-34$ & $10.05^{* * *}$ & $0.42 \mathrm{Xyl}^{*}$ & 0.37 Cell** & -0.14 Lig & & & $0.72 * * *$ \\
\hline
\end{tabular}

Sug free sugars, Fruct fructans, Sol- $C_{N} \mathrm{C}$ in soluble organic N components, Prot $\mathrm{C}$ in proteins, Non-cell non-cellulose structural carbohydrates, e. g. uronic acids and hemicellulose monomers, Ua uronic acids, Hemi hemicellulose monomers, Arab arabinose, Xyl xylose, LigCell lignocellulose, Cell cellulose, Lig Klason lignin

${ }^{*} p=0.05,{ }^{*} p=0.01,{ }^{* * *} p=0.001$ 
composition $\left(R^{2}=0.18\right.$ and 0.87 , respectively). Whether this improved relationship is directly related to the degree of branching of arabinoxylans or only correlated with the levels of arabinose remains to be determined.

Between days 9 and 34, more $\mathrm{C}$ was mineralised from the grasses (20-25\%; Table 2) than from the legumes (12-18\%). The statistical analysis showed a relationship between the amount of $\mathrm{C}$ mineralised and the concentrations of xylan and cellulose in the plant materials. Legumes were characterised by a higher content of branched arabinoxylans but a lower content of linear xylans and cellulose (Table 1). A possible explanation could be that most of the branches consisting mainly of arabinose had already been decomposed at this point, while the decomposition of the xylan backbone and of cellulose was not yet complete. Thus, although the analysis showed a relationship that could be used to predict degradation from the chemical composition, further research is needed to reveal the underlying mechanisms. The rate of lignification is known to reduce the decomposition of structural carbohydrates through physical protection (Berg et al. 1982; Chesson 1997). Although the regression parameter for lignin obtained in our study was negative, the influence was not statistically significant.

The proportion of mineralised $\mathrm{C}$ that originates from primary plant components gradually decreases as decomposition of the plant material progresses (Trinsoutrot et al. 2000). This may explain why no significant relationship was found (adj. $R^{2}=-0.06$ ) between $\mathrm{C}$ mineralisation from day 34 until the end of incubation and slowly decomposing components such as xylan and cellulose in combination with lignin. It seems that after approximately 1 month of decomposition at $20^{\circ} \mathrm{C}$, the grass and legume materials used in the study had become modified to the extent that the components originally present no longer determined the pattern of decomposition.

\section{Conclusion}

Proximate analyses of grass and legume plant materials do not supply sufficient information on the chemical composition of plant materials to explain differences in their pattern of $\mathrm{C}$ mineralisation during early decomposition. This study showed that more detailed chemical analyses of soluble plant components and of the hemicellulose fraction are required. We propose that a minimum set of analyses for legumes and grasses should include free sugars, starch, arabinose, xylan, cellulose and lignin and total N.

Acknowledgements This study was carried out within the Food 21 programme financed by MISTRA. The authors want to thank Prof. Margareta Nyman, Department of Applied Nutrition and Food Chemistry, University of Lund, for valuable discussions on analytical methods and for allowing us to use the departmental laboratory facilities.
Open Access This article is distributed under the terms of the Creative Commons Attribution Noncommercial License which permits any noncommercial use, distribution, and reproduction in any medium, provided the original author(s) and source are credited.

\section{References}

Abivens S, Recous S (2007) Mineralisation of crop residues on the soil surface or incorporated in the soil under controlled conditions. Biol Fertil Soils 43:849-852, DOI 10.1007/s00374007-0165-2

Albrecht KA, Wedin WF, Buxton DR (1987) Cell-wall composition and digestibility of alfalfa stems and leaves. Crop Sci 27:735741

Åman P (1985) Chemical composition and in vitro degradability of major chemical constituents in botanical fractions of red clover harvested at different stages of maturity. J Sci Food Agric 36:775-780, DOI 10.1002/jsfa.2740360903

Åman P (1993) Composition and structure of cell wall polysaccharides in forages. In: Jung HG, Buxton DR, Hatfield RD, Ralph J (eds) Forage cell wall structure and digestibility. American Society of Agronomy Incorporate, Madison, WI, pp 183-199

Asp NG, Johansson CG, Hallmer H, Siljeström M (1983) Rapid enzymatic assay of insoluble and soluble dietary fibre. J Agric Food Chem 31:476-482, DOI 10.1021/jf00117a003

Berg B, Wessén B, Ekbom G (1982) Nitrogen level and decomposition in Scots pine needle litter. Oikos 38:291-296 DOI 10.2307/ 3544667

Bertrand I, Chabbert B, Kurek B, Recous S (2006) Can the biochemical features and histology of wheat residues explain their decomposition in soil? Plant Soil 281:291-307, DOI 10.1007/s11104-005-4628-7

Chesson A (1997) Plant degradation by ruminants: parallels with litter decomposition in soils. In: Cadish G, Giller KE (eds) Driven by nature: plant litter quality and decomposition. $\mathrm{CAB}$ International, Cambridge, pp 47-66

Fruit L, Recous S, Richard G (1999) Plant residue decomposition: effect of soil porosity and particle size. In: Berthelin J, Huang PM, Bollag JM, Andreux F (eds) Effect of mineral-organicmicroorganism interaction on soil and freshwater environments. Kluwer, New York, pp 189-196

Goering HK, van Soest PJ (1970) Forage fibre analyses. Apparatus, reagents, procedures and some application. Agriculture Handbook No 379. USDA, pp 1-19

Gruppen H, Kormelink FJM, Voragen AGJ (1993) Water-unextractable cell wall material from wheat flour. 3. A structural model for arabinoxylans. J Cereal Sci 18:111-128, DOI 10.1006/ jers. 1993.1040

Gunnarsson S, Marstorp H (2002) Carbohydrate composition of plant materials determines $\mathrm{N}$ mineralisation. Nutr Cycl Agroecosyst 62:175-183, DOI 10.1023/A:1015512106336

Henriksen TM, Breland TA (1999) Evaluation of criteria for describing crop residue degradability in a model of carbon and nitrogen turnover in soil. Soil Biol Biochem 31:1135-1149, DOI 10.1016/S0038-0717(99)00031-0

Henriksen TM, Korsaeth A, Breland TA, Stenberg B, Jensen LS, Bruun S et al (2007) Stepwise chemical digestion, near-infrared spectroscopy or total $\mathrm{N}$ measurement to take account of decomposability of plant $\mathrm{C}$ and $\mathrm{N}$ in a mechanistic model. Soil Biol Biochem 39:3115-3126, DOI 10.1016/j.soilbio.2007.06.023

Jung HG, Morrison TA, Buxton DR (1998) Degradability of cell-wall polysaccharides in maize internodes during stalk development. Crop Sci 38:1047-1051 
Kögel-Knabner I (2002) The macromolecular organic composition of plant and microbial residues as inputs to soil organic matter. Soil Biol Biochem 34:139-162, DOI 10.1016/S0038-0717(01)00158-4

Kühbauch W, Kleeberger A (1975) Bacterial decomposition of grassfructosan of different degrees of polymerisation. J Br Grassl Soc 30:223-227

Larsson K, Bengtsson S (1983) Bestämning av lätt tillgängliga kolhydrater i växtmaterial. Statens Lantbrukskemiska Laboratorium, Metodbeskrivning

Marstorp H (1996) Influence of soluble carbohydrates, free amino acids and protein on the decomposition of Lolium multiflorum shoots. Biol Fertil Soils 21:257-263, DOI 10.1007/BF00334901

Marstorp H (1997) Kinetically defined litter fractions based on respiration measurements. In: Cadisch G, Giller KE (eds) Driven by nature: plant quality and decomposition. $\mathrm{CAB}$ International, Cambridge, pp 95-104

Martin JP, Haider K (1986) Influence of mineral colloids on turnover rates of soil organic carbon. In: Huang PM, Schnitzer M (eds) Interactions of soil minerals with natural organics and microbes. Soil Science Society of America, Madison, WI, pp 283-304

Nordgren A (1992) A method for determining microbially available-N and available-P in an organic soil. Biol Fertil Soils 13:195-199, DOI 10.1007/BF00340575

Nordkvist E, Åman P (1986) Changes during growth in anatomical and chemical composition and in-vitro degradability of lucerne. $\mathrm{J}$ Sci Food Agric 37:1-7, DOI 10.1002/jsfa.2740370102

Nordkvist E, Graham H, Åman P (1987) Degradation in vitro and in sacco of red clover leaves and stems. Anim Feed Sci Technol 17:295-304, DOI 10.1016/0377-8401(87)90060-5

Quemada M, Cabrera ML (1995) Carbon and nitrogen mineralisation from leaves and stems of four cover crops. Soil Sci Am J 59:471-477
SAS (1985) SAS user's guide: statistics. SAS Institute, Cary, North Carolina, USA

Seguin P, Mustafa AF, Sheaffer CC (2002) Effects of soil moisture deficit on forage quality, digestibility, and protein fractionation of Kura clover. J Agron Crop Sci 188:260-266, DOI 10.1046/ j.1439-037X.2002.00569.x

StatSoft Inc (2000) STATISTICA for Windows [Computer program manual]. Tulsa, OK

Stotzky G (1965) Microbial respiration. In: Black CA (ed) Methods of soil analysis 2. Agronomy 9, Madison, Wisconsin, pp 1551572

Theander $\mathrm{O}$, Åman $\mathrm{P}$, Westerlund $\mathrm{E}$, Andersson R, Pettersson D (1995) Total dietary fiber determination as neutral sugar residues, uronic acid residues, and Klason lignin (The Uppsala method): collaborative study. J AOAC Int 78:1030-1044

Trinsoutrot I, Recous S, Bentz B, Linères $M$, Chèneby D, Nicolardot B (2000) Biochemical quality of crop residues and carbon and nitrogen mineralization kinetics under nonlimiting nitrogen conditions. Soil Sci Soc Am J 64:918-926

Vailhé MAB, Provan GJ, Scobbie L, Chesson A, Maillot MP, Cornu A et al (2000) Effect of phenolic structures on the degradability of cell walls isolated from newly extended apical internode of tall fescue (Festuca arundinacea Schreb.). J Agric Food Chem 48:618-623, DOI 10.1021/jf9906329

Vinkx CJA, Stevens I, Gruppen H, Gorbet PJ, Delcour JA (1995) Physiochemical and functional properties of rye nonstarch polysaccharides. VI. Variability in the structure of waterunextractable arabinoxylans. Cereal Chem 72:411-318

Wilkie KCB (1979) The hemicelluloses of grasses and cereals. Adv Carbohydr Chem Biochem 36:215-264, DOI 10.1016/S00652318(08)60237-1 